\title{
OŚRODEK OPIEKUŃCZO-REHABILITACYJNY DLA DZIECI I MŁODZIEŻY NIEPEŁNOSPRAWNEJ CARITAS DIECEZJI TARNOWSKIEJ W JADOWNIKACH MOKRYCH $^{1}$
}

\author{
„Miłość jest służbą, którą Kościół pełni, \\ aby nieustannie wychodzić naprzeciw \\ cierpieniom i potrzebom ludzi" \\ (Benedykt XVI, Deus Caritas est, 10)
}

Jadowniki Mokre to najstarsza wioska w gminie Wietrzychowice, położona nad rzeką Kisieliną, otoczona lasami i stawami. Źródła historyczne wymieniają nazwę Jadowniki dopiero w 1411 roku jako własność Stanisława Othy, choć zapewne istniały już w XIII wieku. Mieszkańcy tej osady zajmowali się produkowaniem jadów do zatruwania strzał. Osada miała niewątpliwie charakter służebny. W 1449 roku właścicielem Jadownik był Albert Czapka herbu Nowina. W 1476 roku wioska przeszła w ręce rodziny Pieniążków z Witkowic herbu Jelita. Pierwotnie wieś nosiła nazwę Jadowniki, a nazwa współczesna Jadowniki Mokre datuje się od roku 1518. Ostatnim właścicielem Jadownik Mokrych był Jan Konopka.

Jadowniki Mokre mają również swą męczeńską i heroiczną historię. W okresie II wojny światowej istniało tutaj zorganizowane tajne nauczanie. Wielu mieszkańców Jadownik Mokrych i innych sąsiednich wiosek należało do ruchu oporu,

\footnotetext{
* MGR ADRIANA BŁASZCZYK - kierownik Ośrodka Opiekuńczo-Rehabilitacyjnego dla Dzieci i Młodzieży Niepełnosprawnej Caritas Diecezji Tarnowskiej w Jadownikach Mokrych - surdopedagog, tyflopedagog, asystent osób niepełnosprawnych.

1 Tekst został już opublikowany w: Misericors. 75 lat działalności Caritas Diecezji Tarnowskiej, red. P. Grzanka, Tarnów 2012, s. 383-392.
} 
płacąc za to niejednokrotnie najwyższą cenę. Na jadownickich łąkach, przy wsparciu miejscowych partyzantów, lądowały samoloty z Brindisi w ramach tzw. akcji mostowych („II Most” i „III Most”). Jadowniki Mokre przeżyły również hitlerowską pacyfikację.

To właśnie w tej miejscowości w roku 1938 przyszedł na świat Józef Kowalczyk, syn Stanisława i Katarzyny z domu Łucarz. Po ukończeniu Szkoły Podstawowej w Jadownikach Mokrych i Gimnazjum w Radłowie wstąpił do Wyższego Seminarium Duchownego w Olsztynie. Po otrzymaniu święceń kapłańskich w 1962 roku przez dwa lata pracował jako wikariusz w parafii Świętej Trójcy w Kwidzyniu. W następnym roku rozpoczął studia z prawa kanonicznego na Katolickim Uniwersytecie Lubelskim. W 1965 roku wyjechał do Rzymu i kontynuował studia na Wydziale Prawa Kanonicznego Papieskiego Uniwersytetu Gregoriańskiego. W 1968 roku otrzymał stopień doktora.

W 1967 roku podjął współpracę z Sekretariatem Generalnym Synodu Biskupów, a w 1969 roku w Kongregacji ds. Dyscypliny Sakramentów. W latach 19681971 był słuchaczem Studium Rotalnego, które ukończył z dyplomem adwokata Roty Rzymskiej. W tym czasie uzyskał również dyplom archiwisty w Tajnym Archiwum Watykańskim. W październiku 1978 roku został przeniesiony do Sekretariatu Stanu Stolicy Apostolskiej, gdzie na polecenie papieża Jana Pawła II zorganizował Sekcję Polską i objął jej kierownictwo. Wtedy również został mianowany przewodniczącym Komisji ds. Publikacji Pism Karola Wojtyły, sprzed powołania go na Biskupa Rzymu. Był jednym z najbliższych współpracowników Ojca Świętego.

26 sierpnia 1989 roku Jan Paweł II mianował ks. Józefa Kowalczyka nuncjuszem apostolskim w Polsce, wynosząc go jednocześnie do godności arcybiskupa tytularnego Heraklei. Jako nuncjusz - po 50-letniej przerwie - zorganizował Nuncjaturę Apostolską w Warszawie, przedstawicielstwo dyplomatyczne Stolicy Apostolskiej w Polsce. Był również dziekanem korpusu dyplomatycznego. Jako nuncjusz negocjował i podpisał 28 lipca 1993 roku konkordat pomiędzy Rzeczpospolitą Polską i Stolicą Apostolską, dokonał podziału administracyjnego Kościoła katolickiego w Polsce, tworząc nowe metropolie i diecezje.

8 maja 2010 roku decyzją Ojca Świętego został mianowany Metropolitą Gnieźnieńskim, Prymasem Polski.

Arcybiskup Kowalczyk zawsze dbał o dobro swojej małej Ojczyzny - wioski Jadowniki Mokre. Widząc problemy społeczne jej mieszkańców tj. niepełnosprawność, ubóstwo oraz różnego rodzaju patologie, postanowił - przy współpracy i życzliwości ludzi o otwartym i hojnym sercu - utworzyć Środowiskowy Dom Samopomocy, który ostatecznie przybrał nazwę Ośrodek Opiekuńczo-Rehabilitacyjny 
dla Dzieci i Młodzieży Niepełnosprawnej Caritas Diecezji Tarnowskiej w Jadownikach Mokrych.

Pierwsze oficjalne spotkanie na temat realizacji tej inwestycji miało miejsce 4 marca 1997 roku w Tarnowie w obecności ordynariusza diecezji tarnowskiej bp. Józefa Życińskiego, przedstawicieli Ambasady Republiki Włoskiej: Giuseppe Balboni Acqua i Luca Daniele Biolato, wojewody tarnowskiego Wiesława Wody oraz dyrektora Caritas Diecezji Tarnowskiej księdza Antoniego Mikruta.

9 czerwca 1997 roku Ojciec Święty Jan Paweł II poświęcił kamień węgielny pod budowę Ośrodka. Miało to miejsce w kościele św. Jadwigi w Krakowie w obecności Nuncjusza Apostolskiego w Polsce, ordynariusza diecezji tarnowskiej, dyrektora Caritas oraz przedstawicieli władz samorządowych i mieszkańców Jadownik Mokrych.

5 lipca 1997 roku abp Józef Kowalczyk dokonał uroczystego poświęcenia placu pod budowę Ośrodka. Autorem projektu budynku był architekt Maciej Nejman. Prace budowlane trwały od października 1997 roku do jesieni 2000 roku.

Ośrodek powstał dzięki dotacjom i ofiarom różnych instytucji, takich jak: Komitet Integracji Europejskiej, PFRON, Nuncjatura Apostolska, Fundacja Renovabis z Niemiec, Maltańska Służba z Treviru, KRUS. Oprócz ww. instytucji darczyńcami byli m.in.: ówczesny Nuncjusz Apostolski w Polsce abp Józef Kowalczyk, biskup tarnowski Wiktor Skworc, wojewoda tarnowski Wiesław Woda, wierni diecezji tarnowskiej oraz indywidualni ofiarodawcy z kraju i USA. Pozostałe wydatki pokryła Caritas Diecezji Tarnowskiej, która jest właścicielem Ośrodka.

W czerwcu 2000 roku bp Wiktor Skworc ordynariusz diecezji tarnowskiej powołał na stanowisko dyrektora Ośrodka ks. Marka Koguta, powierzając mu utworzenie struktur organizacyjnych placówki, kierowanie nią i objęcie opieką duszpasterską.

Uroczyste poświęcenie i otwarcie Ośrodka miało miejsce 12 czerwca 2001 roku. Dokonali tego abp Józef Kowalczyk Nuncjusz Apostolski w Polsce oraz bp Wiktor Skworc ordynariusz diecezji tarnowskiej w obecności wielu dostojnych gości.

Jesienią 2000 roku rozpoczęto budowę Domu Miłosierdzia, w którym zamieszkały siostry ze zgromadzenia św. Brata Alberta, świadczące posługę na rzecz podopiecznych Ośrodka.

Następną inwestycją, mającą poszerzyć bazę rehabilitacyjną Ośrodka, była budowa krytego basenu. Rozpoczęto ją pod koniec 2003 roku. Twórcą projektu budowlanego był architekt Adam Krzeczkowski. 1 lipca 2006 roku odbyło się otwarcie i poświęcenie obiektu.

W styczniu 2007 roku rozpoczęto budowę Izby Pamięci Jana Pawła II oraz Domu Czasowego Pobytu dla Pacjentów Ośrodka, którą poświęcono 28 sierpnia 2008 roku w 70. rocznicę urodzin abp. Józefa Kowalczyka. 
Kolejne plany inwestycyjne związane z rozbudową Ośrodka są wynikiem nieustającego zaangażowania abp. Józefa Kowalczyka, obecnego Prymasa Polski w pomoc osobom niepełnosprawnym oraz troski o rozwój Jego Małej Ojczyzny.

Równolegle z rozwojem bazy materialnej, Ośrodek sukcesywnie poszerzał zakres swojej działalności. Pierwszą placówką zaistniałą w strukturach nowopowstałego obiektu był Dom Pomocy Społecznej dla Dzieci i Młodzieży Niepełnosprawnej Intelektualnie. Równocześnie Ośrodek zaczął organizować turnusy rehabilitacyjne dla dzieci i dorosłych. W kolejnych latach powstawały dalsze jednostki: Zakład Rehabilitacji Leczniczej, Niepubliczna Szkoła Podstawowa Specjalna, Niepubliczne Gimnazjum Specjalne, Placówka Opiekuńczo-Wychowawcza Wsparcia Dziennego, Ośrodek Interwencji Kryzysowej.

Ośrodek Opiekuńczo-Rehabilitacyjny dla Dzieci i Młodzieży Niepełnosprawnej Caritas Diecezji Tarnowskiej, mieści się w nowoczesnym obiekcie wybudowanym na powierzchni ok. 2 ha, o łącznej powierzchni użytkowej $3500 \mathrm{~m}^{2}$. Od frontu, między budynkiem, a drogą gminną znajduje się parking dla samochodów. Od strony południowej znajduje się obszerne zaplecze rekreacyjno-sportowe, na które składają się boisko trawiaste, boisko asfaltowe, alejki spacerowe, plac zabaw i hala do hipoterapii. Cały teren dostosowany jest do potrzeb osób niepełnosprawnych, poruszających się na wózkach inwalidzkich.

Ośrodek dysponuje bogatą bazą lokalową, zapewniającą prawidłowy przebieg rehabilitacji, kształcenia i wychowania:

- sale do zajęć edukacyjnych,

- pracownie terapeutyczne,

- sale do zajęć rehabilitacyjnych,

- kryty basen rehabilitacyjny,

- grota solna,

- teren do rekreacji konnej i zajęć hipoterapeutycznych,

- świetlica,

- kaplica.

Ponadto posiada:

- gabinety lekarskie,

- gabinety psychologiczne,

- gabinety logopedyczne,

- dyżurkę pielęgniarską,

- stołówkę.

Sale, w których odbywają się zajęcia edukacyjne, terapeutyczne i rehabilitacyjne wyposażone są w nowoczesny, specjalistyczny sprzęt, urządzenia zapewniające poprawę sprawności psychomotorycznej i pomoce dostosowane do potrzeb i możliwości dzieci niepełnosprawnych. 
Ośrodek Opiekuńczo-Rehabilitacyjny w Jadownikach Mokrych zapewnia szeroki zakres nowoczesnych metod rehabilitacyjnych i terapeutycznych:

\section{Zabiegi z zakresu fizykoterapii:}

- elektroterapia (galwanizacja, jonoforeza, elektrostymulacja, tonoliza, prądy diadynamiczne, interferencyjne, Träuberta, TENS),

- magnetoterapia,

- ultradźwięki,

- światłolecznictwo (laseroterapia, solux, lampa bio-V),

- ciepłolecznictwo (okłady cieplne),

- krioterapia,

- inhalacje,

- hydroterapia.

\section{Zabiegi z zakresu kinezyterapii:}

- gimnastyka korekcyjna,

- gimnastyka ogólnie usprawniająca,

- gimnastyka lecznicza indywidualna w oparciu o nowoczesne metody dostosowane indywidualnie do pacjenta (NDT-Bobath, PNF),

- pionizacja i nauka chodu,

- ćwiczenia w systemie bloczkowo - ciężarkowym w UGUL-u,

- kinezjotaping,

- terapia manualna,

- masaż leczniczy.

\section{Ponadto:}

- hipoterapię,

- dogoterapię,

- terapię zajęciową,

- konsultacje psychologiczne i logopedyczne,

- grupową rehabilitację społeczną.

Ośrodek pełni swą misję poprzez następujące formy działania:

- Dom Pomocy Społecznej dla Dzieci i Młodzieży Niepełnosprawnej Intelektualnie,

- Turnusy Rehabilitacyjne,

- Niepubliczna Szkoła Podstawowa Specjalna,

- Niepubliczne Gimnazjum Specjalne,

- Niepubliczna Szkoła Przysposabiająca do Pracy,

- Zakład Rehabilitacji Leczniczej,

- Placówka Wsparcia Dziennego,

- Ośrodek Interwencji Kryzysowej,

- Centrum Hydroterapii. 
Dom Pomocy Społecznej w Jadownikach Mokrych przeznaczony jest dla dzieci i młodzieży z niepełnosprawnością intelektualną i ruchową wynikającą z mózgowego porażenia dziecięcego, autyzmu, epilepsji i innych schorzeń neurologicznych.

W Placówce panuje ciepła, rodzinna atmosfera sprzyjająca rozwojowi emocjonalnemu i duchowemu mieszkańców. Podopieczni uczestniczą w zajęciach, mających na celu nabycie podstawowych czynności samoobsługowych, przygotowanie do szeroko rozumianego życia w społeczeństwie.

Prowadzona jest także rehabilitacja lecznicza, hipoterapia oraz zajęcia w basenie. Rehabilitacja medyczna obejmuje szeroki zakres zabiegów i ćwiczeń realizowanych według wskazań lekarza, dostosowanych do indywidualnych potrzeb, stanu zdrowia i rodzaju schorzenia. Mieszkańcy Domu są w stałym kontakcie z psychologiem i logopedą, którzy dokonują diagnoz, udzielają porad i prowadzą terapię specjalistyczną.

Założenia terapeutyczne i edukacyjne realizowane są poprzez wprowadzenie zajęć doskonalących motorykę dużą i małą, udział w życiu społecznym w formie organizowanych spotkań integracyjnych.

Dom zapewnia warunki do realizacji potrzeb bytowych, opiekuńczych, wspomagających i edukacyjnych w sposób dostosowany do indywidualnych możliwości mieszkańców:

- wyżywienie, utrzymanie czystości, odzież, obuwie oraz inne potrzeby mieszkańców,

- całodobową opiekę pielęgniarską,

- dostęp do lekarza pierwszego kontaktu oraz do lekarzy specjalistów.

Z podopiecznymi pracuje zespół opiekuńczo-terapeutyczny i medyczno-rehabilitacyjny:

- lekarz (pediatra, neurolog, specjalista rehabilitacji medycznej),

- rehabilitant,

- pielęgniarki,

- opiekunki,

- terapeuta zajęciowy,

- logopeda,

- psycholog,

- duszpasterz,

- pracownik socjalny,

- pedagog specjalny.

Turnusy rehabilitacyjne to dwutygodniowa forma kompleksowej rehabilitacji, organizowana przez Ośrodek przez cały rok dla osób z następującymi schorzeniami: 
- dysfunkcją narządu ruchu,

- upośledzeniem umysłowym,

- mózgowym porażeniem dziecięcym,

- chorobami układu krążenia,

- schorzeniami układu oddechowego,

- epilepsją,

- innymi schorzeniami neurologicznymi.

Celem turnusu jest ogólna poprawa psychofizycznej sprawności oraz rozwijanie umiejętności społecznych uczestników. Ośrodek zapewnia zakwaterowanie $\mathrm{w}$ komfortowych warunkach, pełne wyżywienie z możliwością korzystania ze specjalistycznej diety, całodobową opiekę medyczną, indywidualny program rehabilitacyjny, pedagogiczno-terapeutyczny oraz rekreacyjny.

\section{Zespół rehabilitacyjny tworzą:}

- pielęgniarka,

- fizjoterapeuci,

- hipoterapeuci,

- pedagodzy specjalni,

- lekarz specjalista,

- instruktorzy terapii zajęciowej,

- psycholog,

- logopeda.

Niepubliczna Szkoła Podstawowa Specjalna, Niepubliczne Gimnazjum Specjalne i Niepubliczna Szkoła Przysposabiająca do Pracy to placówki przeznaczone dla dzieci i młodzieży z upośledzeniem umysłowym w stopniu umiarkowanym, znacznym i głębokim. Przystosowane są także do przyjmowania uczniów z niepełnosprawnością ruchową. Szkoła realizuje obowiązujący ramowy program dla szkół specjalnych w zakresie właściwym dla tego typu placówek edukacyjnych i ma uprawnienia szkoły publicznej.

Zadaniem placówki jest wszechstronna pomoc dzieciom i młodzieży niepełnosprawnej w ramach zajęć zespołowych oraz indywidualnych poprzez realizację funkcji wychowawczej, dydaktycznej, opiekuńczej i rehabilitacyjnej. Uczniowie oprócz obowiązkowych zajęć edukacyjnych biorą udział w pozalekcyjnych formach aktywnego wypoczynku tj. dogoterapii, hipoterapii, nauce pływania oraz w zajęciach rekreacyjno-sportowych.

Szkoła Podstawowa obejmuje:

- Oddziały rewalidacyjno-wychowawcze, do których uczęszczają dzieci $\mathrm{z}$ upośledzeniem umysłowym $\mathrm{w}$ stopniu głębokim. Liczba dzieci w grupie wynosi od 2 do 4 . 
- Oddziały edukacyjno-terapeutyczne, do których uczęszczają dzieci z upośledzeniem umysłowym w stopniu umiarkowanym i znacznym oraz z niepełnosprawnością sprzężoną. Liczba dzieci w grupie od 6 do 8 .

Gimnazjum oraz Szkoła Przysposabiająca obejmują:

- Oddziały edukacyjno-terapeutyczne, do których uczęszcza młodzież z upośledzeniem umysłowym w stopniu umiarkowanym i znacznym oraz z niepełnosprawnością sprzężoną. Liczba dzieci w grupie od 6 do 8 .

Zajęcia prowadzone są przez nauczycieli - specjalistów z zakresu: oligofrenopedagogiki, rewalidacji, psychologii, logopedii, tyflopedagogiki, surdopedagogiki i rehabilitacji.

Szkoła posiada dwa mikrobusy, którymi dzieci dowożone są na zajęcia.

Zakład Rehabilitacji Leczniczej świadczy usługi medyczne w ramach umowy z Narodowym Funduszem Zdrowia. Mogą korzystać z nich nieodpłatnie wszyscy zainteresowani, posiadający skierowanie na zabiegi fizjoterapeutyczne od lekarza specjalisty lub skierowanie do poradni rehabilitacyjnej od lekarza rodzinnego. Istnieje również możliwość wykupienia pakietu niezbędnych zabiegów.

Pracownicy Zakładu to wykwalifikowana kadra, w skład której wchodzą: lekarze specjaliści rehabilitacji medycznej oraz rehabilitanci z tytułem magistra.

Placówka oferuje następujące rodzaje świadczeń:

- porady lekarzy - specjalistów rehabilitacji medycznej,

- zabiegi z zakresu fizykoterapii,

- zabiegi z zakresu kinezyterapii.

Placówka Wsparcia Dziennego skupia dzieci pochodzące z najbliższego środowiska, które poszukują możliwości ciekawego spędzania wolnego czasu i rozwijania swoich zainteresowań. Zajęcia prowadzone są w godzinach popołudniowych, pięć razy w tygodniu.

Najważniejszym celem realizowanym przez Placówkę jest prowadzenie działalności środowiskowej na rzecz dziecka i rodziny. Wychowankowie mają zapewnioną realizację szeregu potrzeb, które nie są w pełni zaspokajane w domu i szkole. Przygotowywani są do lepszego funkcjonowania w środowisku społecznym poprzez:

- rozwijanie zaradności i umiejętności współdziałania w grupie rówieśniczej, rodzinie i społeczeństwie,

- udział w zajęciach plastycznych, technicznych, muzycznych oraz kulinarnych,

- integrację z osobami niepełnosprawnymi.

Podopieczni Placówki mają możliwość zjedzenia ciepłego posiłku, uzyskania fachowej pomocy w trudnościach szkolnych oraz brania udziału w szeregu kółek 
zainteresowań. W kształtowaniu osobowości dzieci wychowawcę wspierają: pracownik socjalny, psycholog, logopeda i duszpasterz.

Urozmaiceniem codziennych zajęć są organizowane przez Ośrodek ogniska, imprezy integracyjne, kuligi oraz wycieczki, w których aktywnie biorą udział nie tylko wychowankowie, ale ich rodziny.

Ośrodek Interwencji Kryzysowej działa przy Ośrodku Opiekuńczo-Rehabilitacyjnym Caritas Diecezji Tarnowskiej w Jadownikach Mokrych od grudnia 2006 roku. Jest placówką o zasięgu ponadgminnym dla powiatu tarnowskiego.

Oferta Ośrodka Interwencji Kryzysowej kierowana jest do osób i rodzin będących ofiarami przemocy lub znajdujących się w innych sytuacjach kryzysowych (śmierć bliskiej osoby, utrata pracy, trudności wychowawcze, kłopoty małżeńskie) - wszystkich tych, którzy przeżyli zdarzenia zakłócające dotychczasowy sposób życia, których sytuacje trudne przerastają.

W czasie powodzi, która nawiedziła Jadowniki Mokre i okoliczne miejscowości w 2010 roku Ośrodek Interwencji włączył się wraz ze specjalistycznymi służbami $\mathrm{w}$ organizowanie pomocy potrzebującym.

Centrum Hydroterapii powstało w 2006 roku. Stanowi kompleks, składający się z basenu rehabilitacyjnego, wyposażonego w urządzenia do masażu wodnego, kanału dla terapeutów, jacuzzi oraz nowocześnie wyposażonej sauny.

Z basenu na co dzień korzystają uczestnicy turnusów rehabilitacyjnych, dzieci z Niepublicznej Szkoły Specjalnej, Placówki Wsparcia Dziennego i Domu Pomocy Społecznej. Na zajęcia nauki pływania przyjeżdżają dzieci i młodzież z pobliskich placówek. Basen pełni także funkcję rekreacyjną dla mieszkańców z okolicznych miejscowości.

Nad bezpieczeństwem pływających czuwa wykwalifikowana kadra, a zajęcia rehabilitacyjne w wodzie prowadzone są przez specjalistów.

9 maja 2003 roku Ośrodek otrzymał od abp. Józefa Kowalczyka i jego siostry, Marii Kowalczyk-Smoleń cenny dar - dom rodzinny, mieszczący się w przysiółku Jadownik Mokrych Dębowe Domy. Przekazanie ojcowizny odbyło się w obecności biskupa tarnowskiego Wiktora Skworca, notariusza Zofii Rzeźniewskiej, ofiarodawców oraz dyrektora Ośrodka.

W pobliżu domu znajduje się figura Matki Boskiej Fatimskiej ufundowana w darze wdzięczności arcybiskupowi J. Kowalczykowi przez mieszkańców Jadownik. Lokalną tradycją stały się cykliczne pielgrzymki parafian do tego miejsca od maja do października 13 dnia miesiąca.

W 2007 roku powstało tzw. ranczo, czyli obiekt mieszczący grill otwarty, pomieszczenie z kominkiem oraz zaplecze sanitarne. Ranczo wykorzystywane jest na plenerowe spotkania integracyjne. 
Izba Pamięci została poświęcona 28 sierpnia 2008 roku przez abp. Józefa Kowalczyka, ówczesnego Nuncjusza Apostolskiego w Polsce. Łączy ona dotychczasową działalność charytatywną Ośrodka z miejscem upamiętniającym osobę Ojca Świętego oraz posługę abp. Józefa Kowalczyka. Jest również materialnym znakiem składanego im hołdu za wszystko, co uczynili osobom niepełnosprawnym.

Izba Pamięci składa się z dwóch części. W górnej kondygnacji zgromadzono pamiątki związane z osobą św. Jana Pawła II. Wśród eksponatów znajdują się m.in. sutanna, narty papieskie oraz inne osobiste przedmioty. W muzeum zgromadzono również bogatą korespondencję między Nuncjuszem Apostolskim a Ojcem Świętym, medale wybite z okazji kolejnych lat pontyfikatu Jana Pawła II, okolicznościowe monety oraz bogatą spuściznę pisarską Karola Wojtyły.

$\mathrm{W}$ dolnej kondygnacji muzeum zostały zebrane pamiątki związane z życiem i posługą abp. Józefa Kowalczyka. Wśród wielu ciekawych eksponatów znajdują się liczne pamiątki związane $\mathrm{z}$ udziałem w podróżach zagranicznych $\mathrm{z}$ Janem Pawłem II, dokumenty związane z pracą ks. J. Kowalczyka w Watykanie - zarówno w sekretariacie synodu biskupów, jak i sekcji polskiej Sekretariatu Stanu. Kolejne eksponaty pochodzą z okresu wypełniania misji Nuncjusza Apostolskiego w Polsce, a także upominki ofiarowane przez ambasadorów różnych państw, z którymi współpracował jako dziekan korpusu dyplomatycznego. Jedna z gablot zawiera dokumenty związane z reorganizacją struktur administracyjnych Kościoła w Polsce, której Nuncjusz Apostolski był autorem.

W pawilonie, oprócz Izby Pamięci, mieści się dom czasowego pobytu dla pacjentów Ośrodka.

Na zewnątrz muzeum, w krużgankach, wyeksponowano zdjęcia przedstawiające historię Jadownik Mokrych, szczególnie tragiczne dzieje wojenne, jak np. operacja pn. „Akcja III Most”. Wykorzystane są także zdjęcia ukazujące życie i posługę abp. Józefa Kowalczyka. Znajduje się tam również amfiteatr, w którym odbywają się występy dzieci z Ośrodka.

Od września 2011 roku przy Ośrodku funkcjonuje sala terapeutyczno-inhalacyjna, grota solna.

Dobroczynne działanie soli, znane jest od dawna. Naturalna sól posiada komplet mikroelementów gwarantujący powstanie w grocie solnej specyficznego mikroklimatu. Czyste, zjonizowane powietrze odpręża i wspomaga leczenie wielu chorób.

Specjalny system podgrzewania i wentylacji ścian solnych sprawia, że sól paruje, jonizując ujemnie powietrze oraz nasycając je cennymi dla zdrowia biopierwiastkami. Seans relaksacyjno-inhalacyjny odbywa się w atmosferze całkowitego wyciszenia, z wykorzystaniem muzykoterapii i światłoterapii. 
Energiczny rozwój Ośrodka w ciągu minionych 11 lat, jest owocem wytężonej pracy wykwalifikowanego zespołu ponad stu osób, który tworzą: rehabilitanci, pedagodzy, lekarze, pielęgniarki, psycholodzy, logopedzi, hipoterapeuci, dogoterapeuci, instruktorzy terapii zajęciowej, opiekunki osób niepełnosprawnych, pracownicy administracyjno-biurowi, pracownicy gospodarczy. Wszyscy oni na co dzień swoją ofiarną służbą świadczą pomoc niepełnosprawnym, chorym oraz znajdującym się w potrzebie. Wypełniają tym samym wezwanie Ojca Świętego Jana Pawła II do wrażliwości na ludzkie cierpienie i czynnie realizują chrześcijańską wyobraźnię miłosierdzia.

\begin{tabular}{|c|c|c|c|c|c|}
\hline Dane & 2010 & 2009 & 2008 & 2007 & 2006 \\
\hline Liczba osób na turnusie rehabilitacyjnym & 805 & 956 & 1020 & 945 & 788 \\
\hline Liczba studentów odbywających praktyki & 251 & 215 & 194 & 180 & 235 \\
\hline Liczba osób na stażu & 9 & 12 & 8 & 1 & o \\
\hline $\begin{array}{l}\text { Liczba porad lekarskich udzielonych w Zakładzie Rehabi- } \\
\text { litacji Leczniczej }\end{array}$ & 1356 & 1169 & 1241 & 1168 & 1488 \\
\hline Liczba pacjentów Działu Fizjoterapii & 1749 & 1890 & 1583 & 1149 & 1118 \\
\hline $\begin{array}{l}\text { Liczba zabiegów wykonanych w Zakładzie Rehabilitacji } \\
\text { Leczniczej }\end{array}$ & 59123 & 55436 & 54210 & 44020 & 48550 \\
\hline $\begin{array}{l}\text { Liczba podopiecznych Placówki Opiekuńczo-Wychowaw- } \\
\text { czej Wsparcia Dziennego }\end{array}$ & 23 & 24 & 24 & 30 & 30 \\
\hline Liczba uczniów Niepublicznej Szkoły Specjalnej & 41 & 41 & 39 & 38 & 37 \\
\hline $\begin{array}{l}\text { Liczba oddziałów rewalidacyjno-wychowawczych w Szko- } \\
\text { le Podstawowej }\end{array}$ & 4 & 4 & 4 & 4 & 3 \\
\hline $\begin{array}{l}\text { Liczba dzieci uczęszczających na lekcje pływania w ramach } \\
\text { umów ze szkołami }\end{array}$ & 220 & 260 & 260 & 260 & 90 \\
\hline $\begin{array}{l}\text { Liczba porad udzielonych ofiarom przemocy lub innych sy- } \\
\text { tuacji kryzysowych }\end{array}$ & 290 & 237 & 217 & 167 & 13 \\
\hline $\begin{array}{l}\text { Liczba osób korzystających z telefonu zaufania w Ośrodku } \\
\text { Interwencji Kryzysowej }\end{array}$ & 22 & 24 & 23 & 22 & 10 \\
\hline $\begin{array}{l}\text { Liczba rodzin korzystających z Ośrodka Interwencji } \\
\text { Kryzysowej }\end{array}$ & 65 & 49 & 26 & 18 & 6 \\
\hline Liczba osób korzystających z hostelu OIK & 70 & 20 & 21 & 22 & 1 \\
\hline Liczba pracowników wykonujących powyższe zadania & 107 & 100 & 100 & 88 & 84 \\
\hline
\end{tabular}

